\title{
Taxonomic resolution refinement does not improve understanding of invertebrate's role on leaf litter breakdown
}

\author{
R. de S. Rezende',2,5, A. O. Medeiros³, J. A. dos Santos Dahora³, A. M. Tonin²,
} J. F. Gonçalves Junior ${ }^{2}$ and Y. Moretto 4

${ }_{1}^{1}$ Program of Postgraduate in Environmental Science, Communitarian University of Chapecó Region, CEP: 89.809-000, Santa Catarina, Brazil

2 Limnology/AquaRiparia Lab., Department of Ecology, IB, University of Brasilia (UnB), Asa Norte, 70910-900, Brasília, DF, Brazil

${ }^{3}$ Environmental Microbiology Lab. Institute of Biology, Federal University of Bahia, CEP 40170-110 Salvador, Bahia, Brazil

${ }^{4}$ Program of Postgraduate on Aquaculture and Sustainable Development, Laboratory of Benthic Aquatic Invertebrates, Department of Biodiversity, Federal University of Paraná, CEP: 85950-000, Palotina, Brazil

${ }^{5}$ Corresponding author. renanrezende30@gmail.com

Keywords: Filtering-collectors, Fungus sporulation, Gathering-collectors, Hyphomycetes, Predators, Shredders.

Abstract: The invertebrate biodiversity of subtropical streams depends on the seasonal input of organic matter, as much as the leaf decomposition process on stream system. However, one of the challenges in determining the importance of invertebrates for leaf breakdown in subtropical streams is the low taxonomic resolution applied in most studies. To overcome this limitation, here we used litter bags with senescent leaves to evaluate the impact of different taxonomic resolutions of trophic group classification to assess the seasonal importance of invertebrate community for leaf litter breakdown in a subtropical stream (Atlantic Forest in western of Paraná state, Brazil). Litterfall was quarterly measured over a year. The leaf litter accumulated in an interval of 30 days was retrieved, weighed, and used for the leaf breakdown experiments (by litter bags). We found a lower importance of invertebrate community richness and density (shredders and scrapers) in leaf breakdown process irrespective of the taxonomic resolution (family or genus level used). Hyphomycetes biomass and fungi sporulation also did not present changes among sample times, and consecutively, importance for leaf breakdown. However, the richness and density of Chironomidae taxa respond differently depending on the taxonomic resolution used. Low litter breakdown may be explained by the increase of consumption of microorganisms, due to high density of Chironomidae scrapers evaluated at the genus level. Moreover, temperature is the main factor responsible for breakdown over the year, in a positive way. Therefore, our results indicated the family level as the taxonomic resolution sufficient to assess the role of shredders and scrapers in the leaf litter breakdown process of this subtropical stream system.

Abbreviations: AOM-Allochthonous Organic Matter, AFDM-Ash-Free Dry Mass, D.O.-Dissolved Oxygen, El.Cond.Electric Conductivity, E:S-Error by Sites, E:R-Error Residuals, FFG-Functional Feeding Group, k-decay rate, PerMANOVAPermutational Multivariate Analysis of Variance, RM-ANOVA-Repeated Measures ANOVA, TS-Temporal Sampling, W.T.Water Temperature, W.F.-Water Flow

\section{Introduction}

Aquatic communities are fueled by allochthonous organic matter (AOM) entering headwater streams, which are mainly composed by leaf litter (Gonçalves et al. 2012a, Bambi et al. 2017). Given the light limitation by canopy shading, food webs in headwater streams depend upon energy sources from AOM (Gessner 1999, Graça et al. 2015). The increase in the environmental heterogeneity by the input of AOM with a high diversity of leaf substrate (Dolédec et al. 2011, Rezende et al. 2014b) is one of the main factors controlling the decomposer communities (Harper et al. 1997, Rezende et al. 2014b, Graça et al. 2015). Therefore, the evaluation of these factors should be taken into account for understanding the ecosystem functioning of tropical headwater streams (Rezende et al. 2014a, Graça et al. 2015).
The interactions among the input of AOM, aquatic communities and environmental heterogeneity may be measured by leaf litter breakdown process (Rezende et al. 2014a, 2015). Leaf litter breakdown process is essentially driven by microbial community (mainly bacteria and hyphomycetes; Graça et al. 2015, 2016), a step known as conditioning. Bacteria decompose labile molecules as secondary metabolites, and aquatic fungi (hyphomycetes) mineralize through enzymatic action the structural and recalcitrant compounds (Graça et al. 2015,2016 ). After this time, the quality of leaf litter increases its quality (mainly by hyphomycetes action), influencing invertebrates' colonization through degradative ecological succession and their capacity of feeding of this substrate (Gonçalves et al. 2004, 2012a, Ligeiro et al. 2010).

The leaf litter mineralization by decomposition is a continuous process in trophic webs, which can be also influ- 
enced by abiotic factors (Gessner 1999, Graça et al. 2015). For example, high water nutrient concentrations can increase the rate of leaf litter breakdown by increasing the activity of decomposers (Rezende et al. 2014a, Sales et al. 2015). Also, natural changes in abiotic factors along a seasonal gradient may include an increase in the stream width, changes in water velocity by rain and dry cycles, and light penetration in the riparian canopy (and increase the temperature) by phenology of riparian vegetation (Rezende et al. 2016, 2017a). Along a seasonal gradient, from the rain to the dry season, may be observed an increase in the abundance of micro-organisms and a decrease in invertebrates (primarily shredders of AOM; Rezende et al. 2014b, 2016, 2017a). Therefore, the direct and indirect effects of leaf breakdown processes on decomposer communities should be evaluated for better understanding the trophic interactions of tropical streams (Rezende et al. 2014a, 2017a).

In decomposer communities, shredders constitute the main trophic group due to the direct use of leaf tissue for feeding (Graça 2001, Ferreira et al. 2006, Moulton et al. 2010). The shredders activity may increase the incorporation of litter in secondary production and fine particles which are used as food by collectors and filterers (González and Graça 2005). However, the low shredders abundance found in leaf colonization remain unclear for tropical streams (Moulton et al. 2010, Boyero et al. 2011, 2012, Rezende et al. 2015). On the other hand, studies have shown that scrapers may fragment the plant tissues by consuming the periphyton and also present a high abundance in tropical streams (Rezende et al. 2010, Rezende et al. 2017a). In this sense, the role of specific invertebrates and trophic feeding groups in leaf breakdown in subtropical stream is not well understood (Biasi et al. 2016, Wang et al. 2017).

The current challenge is to determine the importance of invertebrates for leaf breakdown in tropical/subtropical streams mainly due to the low taxonomic resolution used in most of the studies (e.g., Compin and Céréghino, 2003, Rueda-Delgado et al. 2006). For example, the majority of the studies usually evaluate the invertebrate community at the family level, classifying organisms into more than one functional group (Cummins et al. 2005, Gonçalves et al. 2014). This is even more dramatic for the Chironomidae family, which is generally the predominant insect group on decomposing leaves (Gonçalves et al. 2003, 2016, Biasi et al. 2013, Rezende et al. 2017c,a) and are often neglected in functional feeding group classification as a consequence of difficulties in genus or species identification (Cummins et al. 2005, Gonçalves et al. 2014, Heino et al. 2018). Therefore, studies using fine taxonomic resolution at genus or species levels are an important step to unravel the importance of invertebrates in subtropical as well as in tropical streams (Biasi et al. 2013, Heino et al. 2018).

Our objective was to assess the importance of invertebrate community (using different taxonomic resolutions for trophic group classification) in leaf litter breakdown in a subtropical stream during a year. We used models of repeated measures ANOVA (RM-ANOVA) to verify if the refined taxonomic resolution would alter the understanding of the invertebrates influence in leaf breakdown. Differences between taxonomic resolutions (comparing the RM-ANOVA models patterns) indicate the importance of the factor for leaf breakdown. Also, the same patterns among any decomposer community with the mass loss (by RM-ANOVAs models) will highlight the important factors for leaf breakdown. We, thus, tested two hypotheses: (1) shredder and scraper invertebrates would be relatively more important for leaf breakdown than other invertebrates, fungi and environmental variables; and (2) the degree of taxonomic resolution enhances the accuracy of the importance of invertebrates for leaf breakdown process.
Figure 1. Location of the sampling point in the Quati Stream on São Camilo State Park, Palotina City, Paraná State.

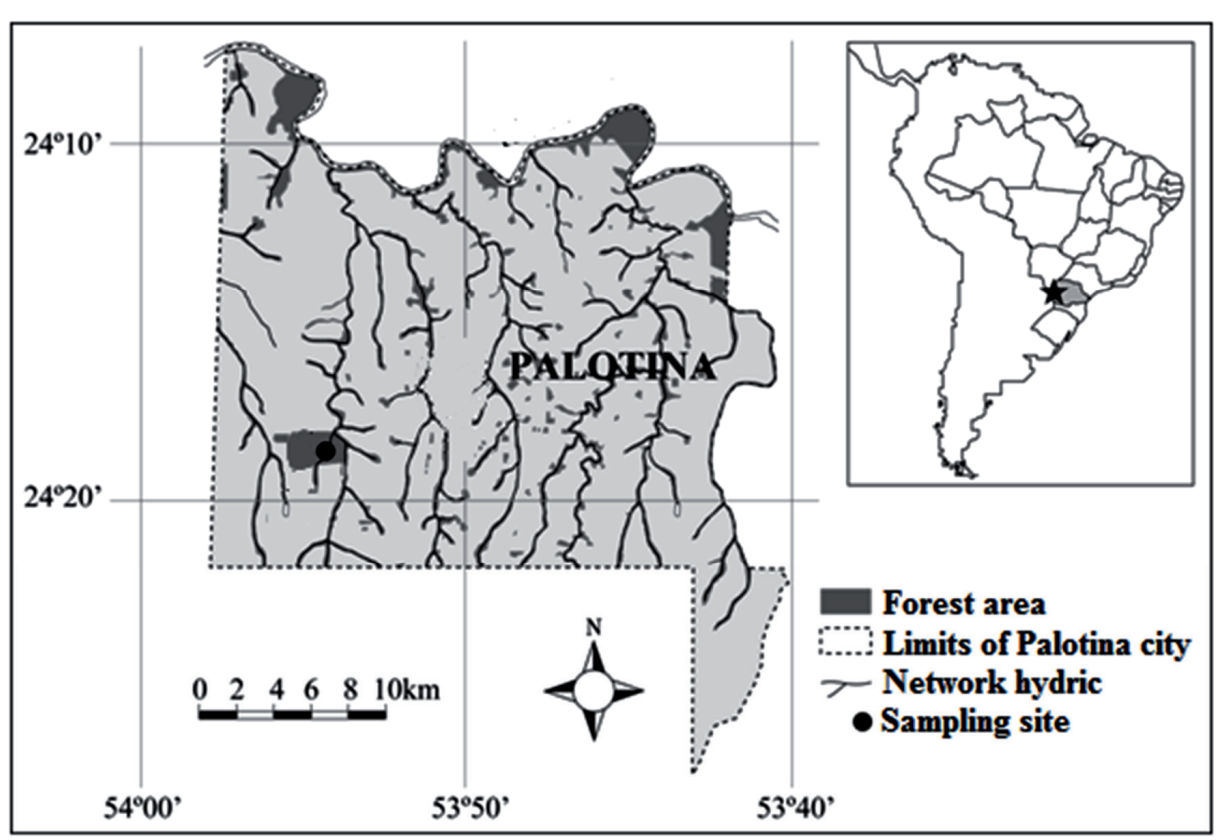


Table 1. Mean and standard error values of the environmental variables in sampling times on Quati Stream.

\begin{tabular}{lccccc}
\hline \multicolumn{1}{c}{ Month } & W.T. $\left({ }^{\circ} \mathrm{C}\right)$ & D.O. $(\mathrm{mg} . \mathrm{L})$ & $\mathrm{pH}$ & El. Cond. $(\mu \mathrm{S} . \mathrm{cm})$ & W.F. $\left(\mathrm{m}^{3} . \mathrm{s}\right)$ \\
\hline January & $21.12 \pm 0.09$ & $9.17 \pm 0.04$ & $5.55 \pm 0.01$ & $50.72 \pm 0.81$ & $0.30 \pm 0.01$ \\
April & $19.14 \pm 0.08$ & $9.45 \pm 0.11$ & $6.90 \pm 0.01$ & $31.00 \pm 0.01$ & $0.27 \pm 0.02$ \\
August & $14.29 \pm 0.18$ & $9.44 \pm 0.13$ & $7.39 \pm 0.34$ & $36.40 \pm 1.50$ & $0.32 \pm 0.01$ \\
November & $20.67 \pm 0.05$ & $8.76 \pm 0.33$ & $6.91 \pm 0.19$ & $64.44 \pm 0.92$ & $0.36 \pm 0.03$ \\
\hline
\end{tabular}

\section{Material and methods}

Study area

The experiment was performed in a first order stream (Quati stream, with ca. $3.3 \mathrm{~km}$ extension), located in the Conservation Unit of São Camilo State Park (total area of 385.34 ha) in the western of Paraná state, Brazil (Fig. 1). Natural vegetation is tropical seasonal semideciduous forest of Atlantic forest domain (Oliveira-Filho et al. 2006). The climate is Cfa type (according Köppen classification), with hot and rainy summers, rare frost formation and with a defined dry season during the winter season.

\section{Procedures}

Litterfall was measured in four different occasions within a year (December 2013, March, July and October 2014) covering all periods (seasons) over the year. Litterfall measurements were done in five sampling points (Supplement: Fig. SM1) spaced 20 meters from each other, for a total length of 100 meters along the stream (additional details are available in Sales et al. 2015, Rezende et al. 2016, Tonin et al. 2017). Plant litter (only leaf litter) directly entering in the stream (vertical input - VI) was measured at each sampling point using three rows with six buckets each (total area of $0.53 \mathrm{~m}^{2}$ ), suspended $2 \mathrm{~m}$ above the stream with ropes (Rezende et al. $2017 \mathrm{~b}$ ). The bucket bottoms were perforated to allow rainwater to evacuate.

The litter accumulated in the buckets in an interval of 30 days was retrieved and weighed in situ (wet weight), and the contents of the bucket with the highest leaf litter mass in each row were used for the leaf litter breakdown experiments ( 1 leaf litter by row $\times 3$ rows $\times 5$ points $\times 4$ months $=$ 60 replicates). The contents of the remaining buckets (only leaf litter), which were not used in the leaf litter breakdown experiment were oven dried to a constant mass $\left(60^{\circ} \mathrm{C}, 72 \mathrm{~h}\right)$, and the resulting weight was used as a correction factor to estimate the moisture of the litter used in the leaf litter breakdown experiment.

A multianalyzer (model 85, YSI Incorporated) was used to measure in situ temperature $\left({ }^{\circ} \mathrm{C}\right)$, electrical conductivity $\left(\mu \mathrm{S} \mathrm{cm}{ }^{-1}\right), \mathrm{pH}$ (measured using YSI's EcoSense pH100A), and dissolved oxygen $\left(\mathrm{mg} \mathrm{L}^{-1}\right)$. At each sampling occasion were measured current velocity $\left(\mathrm{m} \mathrm{s}^{-1}\right.$; using a flow meter, Sigma Sports model FP101, Global Water), water depth and wetted width of five stream sections (using a measuring tape). The mean of water temperature was $18^{\circ} \mathrm{C}$, with the highest value in January $\left(21^{\circ} \mathrm{C}\right.$; summer $)$ and lowest in August $\left(14^{\circ} \mathrm{C}\right.$; winter). The Quati stream had high discharge (mean flow $=$ $0.31 \mathrm{~m}^{3} . \mathrm{s}$ ) and elevated oxygen dissolved in water (range in 8.76 to $9.45 \mathrm{mg} .1$ ). Finally, the stream presents circumneutral water and higher electrical conductivity (Table 1). A sediment sample was collected from each sampling site using a plastic container to determine the granulometric composition and organic matter content of the sediment. The granulometric composition of the sediment was determined according to the methodology proposed by Suguio (1973).

\section{Leaf litter breakdown and decomposer community}

We only used leaves from the vertical input for leaf litter breakdown experiment for each period (seasons) over the year. The leaves were weighed and placed in litter bags (30 $\mathrm{cm} \times 30 \mathrm{~cm}$, with a $10 \mathrm{~mm}$ mesh), and submerged for 30 days (each litter bag contained leaf litter from one bucket) on January, April, August and November. The amount of material placed in the bags ranged from 1 to $3 \mathrm{~g}$ (litter bags had different sample weight due to quarterly changes in litterfall throughout the year), and after a three-month period the leaf litter samples were removed and replaced with new ones (Sales et al. 2015, Rezende et al. 2016, 2017a). The collected litter bags were transported to the laboratory in a cooler.

The leaf litter remains were washed with distilled water over a $250 \mu \mathrm{m}$ sieve in the laboratory, and the collected invertebrates were fixed in $70 \%$ ethanol. Invertebrates were later identified to family and genus, and classified into functional trophic groups as follows: gathering-collectors, filteringcollectors, shredders, scrapers, and predators, according to Pérez (1988), Cummins (1996), Cummins et al. (2005), and Hamada et al. (2014).

Leaf discs (12 $\mathrm{mm}$ diam.) were removed with a cork borer from five randomly selected leaves and grouped into three sets with 5 discs each to be used to determine ash-free dry mass (AFDM; for correction of inorganic compounds), and fungi analyses (biomass by ergosterol and sporulation rates). We calculated the AFDM by subtracting the ash weight (muffle in $750^{\circ} \mathrm{C}$ for $4 \mathrm{~h}$ ) from dry weight. The remaining leaf litter was placed in aluminum trays and dried in an oven at 60 ${ }^{\circ} \mathrm{C}$ for $72 \mathrm{~h}$ to determine dry weight.

The biomass of the fungi associated with the decomposing leaf litter was assessed by ergosterol content according to Gessner (2005). Ergosterol was extracted by boiling the samples in $\mathrm{KOH} / \mathrm{methanol}$, and the obtained extract was filtered. The ergosterol was then eluted in isopropanol and analyzed by high-performance liquid chromatography, and then 
compared against a standard curve using the curve area as reference. Conidial production by aquatic hyphomycetes associated with the decomposing leaf litter was determined by five leaf discs incubated in Erlenmeyer flasks with $30 \mathrm{~mL}$ of deslilled water on an orbital shaker ( $900 \mathrm{rpm})$ for $48 \mathrm{~h}$ at 18 ${ }^{\circ} \mathrm{C}$ (Bärlocher 2005). Aliquots of conidial suspensions of released spores $(10 \mathrm{~mL})$ were filtered through a Millipore membrane filter (pore size $25 \mu \mathrm{m}$ diameter, Millipore Corporation, Bedford, MA, USA), stained $(0.1 \%$ cotton blue in lactophenol) and examined under an optical microscope $(\times 400$, Olympus BX 43) to estimate the number of conidia retained. Sporulation rates were expressed as number of conidia $\mathrm{mg}^{-1}$ AFDM d ${ }^{-1}$, also counting and identified to specie according to Gulis (2005) and aided by Fiuza et al. $(2015,2016)$.

\section{Statistical analysis}

Leaf litter breakdown rates $(k)$ were calculated using a negative exponential model of the percent of mass lost over time ( $W_{t}=W_{0} e^{-k t} ; W_{t}=$ remaining weight; $W_{0}=$ initial weight; $-k=$ decay rate; $t=$ time). The normality of the biological variables was tested using a Kolmogorov-Smirnov test, and the variables were transformed as necessary $\left(\log _{10} x+1\right)$.

We tested the remaining mass, leaf litter input, fungal biomass (by ergosterol) and sporulation, invertebrate density, invertebrate richness, shredders abundance and scrapers abundance (dependent variable) in relation to seasonal sampling times (February, April, August and November) by oneway repeated measures ANOVA (RM-ANOVA). We used the stream stretch (5 sampling points) as repeated measurements to run the RM-ANOVA (Crawley 2007). The RM-ANOVA is typical for experiments with different error variances and pseudoreplication corrections (for more see also chapter 11 of Crawley 2007). Differences among the categorical variables (sampling times) were assessed through orthogonal contrast analysis (Crawley 2007). In this analysis, the dependent variables for the different seasonal sampling times (February, April, August and November) were ordered (ascending) and tested pairwise (with the closest values) and sequentially by adding to the model values with no differences and testing with the next model in a stepwise model simplification process (for more see also chapter 9 of Crawley 2007). Comparisons of the patterns of RM-ANOVA models were used to check the importance of taxonomic resolution. Similar patterns indicate that the taxonomic resolution is not important for leaf breakdown. Any similarity among taxonomic resolutions and mass loss (RM-ANOVAs models), highlight and identify the importance of taxonomic degree for leaf breakdown. The association between some of the variables was assessed with Spearman's correlation (Crawley 2007).

The invertebrates and hyphomycetes communities (abundance and richness) were tested to assess whether there are differences between sampling times using a Permutational Multivariate Analysis of Variance (PerMANOVA) and parcontrast analyses (Bonferroni correction). The PerMANOVA was discriminated by Bonferroni-corrected pairwise comparison (distance matrix of Bray-Curtis, 10000 permutation and with pseudo-F; Adonis function, vegan package for R; Oksanen et al. 2008, R Core Team 2019).

\section{Results}

\section{Invertebrate community}

Total of 2522 specimens from 34 families and 151 genera were collected (Supplement: Table SM2). The mean density of leaf-associated invertebrates found in this study was $28 \mathrm{~g}^{-1}( \pm 4$ Standard Error - SE). The most abundant taxa were Chironomidae (40\%) and Oligochaeta (12\%). The mean species richness was 15 taxa $( \pm 2 \mathrm{SE})$ per litter bag. The genera with higher abundance were Rheotanytarsus (10\%; Chironomidae) followed by Hexacylloepus (8\%; Elmidae), Heterelmis (6\%; Elmidae), Heteragrion (4\%; Megapodagrionidae) and Neoelmis (3\%; Elmidae). The invertebrate density and richness did not differ among sampling times (Table 2; Fig. 2). We only found a positive correlation between richness with coarse sand $(r=0.39, p=0.045$; Spearman correlation) and very coarse sand $(\mathrm{r}=0.40, \mathrm{p}=$ 0.045 ; Spearman correlation). The structure and composition of invertebrate community changed among sample times (PerMANOVA; $\mathrm{F}_{(4,54)}=2.95 ; \mathrm{p}<0.001$ ), with the exception of the comparison between January and April (Bonferronicorrected pairwise $\mathrm{p}<0.05$ ).

The gathering-collectors was the more abundant functional feeding group (50\%), followed by predators $(25 \%)$ and scrapers (14\%; fragment leaf litter by scraping the perifiton through the radula). Filtering-collectors trophic group (9\%) and shredders ( $2 \%$; most important trophic group due to break down leaf matter) have had lower abundances (Supplement: Table SM3). Shredders show a higher density in November compared to other months, but scrapers did not differ among sampling times (Table 2; Fig. 2). Shredders also show a positive correlation only with coarse sand $(\mathrm{r}=0.72, \mathrm{p}=0.045)$ and very coarse sand $(r=0.41, p=0.044$; Spearman correlation). However, scrapers did not present correlation with the evaluated factors. Finally, the taxonomic resolution did not change the patterns observed for scrapers and shredders (family to genus level), presenting the same result also for Chironomidae in genus level (Table 3 and Fig. 3). However, an increase was observed in scrapers and shredders abundance along with the increase in taxonomic resolution.

\section{Environmental variables and ecological process}

The average mass loss was $27 \%$ ( \pm 2.2 Standard Error), with lower values in April $(21 \% \pm 1.2)$ and higher values in August $(33 \% \pm 3.4)$. The mean decomposition coefficient ("k") was -0.046 day $^{-1}$ and ranged from -0.037 (August) to -0.052 (April). August was the month with lower values of remaining mass (Table 2; Fig. 2). The mass loss showed a positive correlation with water temperature $(\mathrm{r}=0.42, \mathrm{p}=0.047$; Spearman correlation).

Fungal biomass was higher in April (total mean of ergosterol $198 \pm 20 \mu \mathrm{g} \mathrm{g}^{-1}$ AFDM; Fig. 2). Fungal biomass 
Table 2. One-way RM-ANOVA of mass loss (A). fungal biomass (by ergosterol B). invertebrate density $(\mathrm{C})$. invertebrate richness (D). shredders abundance (E) and scrapers abundance (F) among sampling times (January. April. August and November) in a subtropical stream and the contrast analysis $(\mathrm{p}<0.05)$. Error by sites in repeated measurements (E:S), error residuals (E:R), temporal sampling (TS) and residuals are represented.

\begin{tabular}{cccccl}
\hline ANOVA & DF & Sum Sq & F value & $\operatorname{Pr}(>\mathrm{F})$ & $\begin{array}{l}\text { Contrast } \\
\text { Analysis }\end{array}$ \\
\hline $\begin{array}{c}\text { A. Mass loss } \\
\text { E:S }\end{array}$ & 1 & 0.08 & 0.11 & & \\
E:R & 3 & 2.47 & & & \\
TS & 3 & 19.43 & 4.24 & 0.009 & $\begin{array}{l}\text { August }< \\
\text { November }= \\
\text { January }= \\
\text { April }\end{array}$ \\
& & & & & \\
Residuals & 51 & 78.01 & & & \\
\hline B. Ergosterol & & & & & \\
E:S & 1 & 0.48 & 0.34 & & \\
E:R & 3 & 3.02 & & & $\begin{array}{l}\text { January }= \\
\text { November }= \\
\text { August }< \\
\text { TS }\end{array}$ \\
& 3 & 86.77 & 4.32 & 0.010 \\
Residuals & 51 & 9.73 & & & April \\
\hline
\end{tabular}

C. Invertebrate Richness

\begin{tabular}{ccccc} 
E:S & 1 & 0.02 & 0.01 & \\
E:R & 3 & 12.64 & & \\
TS & 3 & 12.23 & 2.60 & 0.072 \\
Residuals & 51 & 75.11 & & \\
\hline
\end{tabular}

D. Invertebrate Density

\begin{tabular}{ccccc} 
E:S & 1 & 1.75 & 1.32 & \\
E:R & 3 & 3.98 & & \\
TS & 3 & 3.02 & 0.53 & 0.664 \\
Residuals & 51 & 91.25 & & \\
\hline
\end{tabular}

\begin{tabular}{cccccc}
\hline E. Shredders \% & & & & \\
E:S & 1 & 0.07 & 0.17 & & \\
E:R & 3 & 1.21 & & & $\begin{array}{l}\text { January }= \\
\text { August }= \\
\text { April }< \\
\text { November }\end{array}$ \\
TS & 3 & 39.99 & 10.67 & $<0.001$ \\
& & & & & \\
Residuals & 51 & 58.73 & & & \\
\hline F. Scrapers \% & & & & & \\
E:S & 1 & 0.27 & 0.27 & & \\
E:R & 3 & 2.17 & & & \\
TS & 3 & 9.78 & 1.74 & 0.171 & \\
Residuals & 51 & 87.83 & & & \\
\hline
\end{tabular}

(Table 2) and sporulation (RM-ANOVA; $\left.\mathrm{F}_{3,35}\right)=0.52$; $\mathrm{p}=0.676)$ did not correlate with the factors. We found 14 species of hyphomycetes (Anguilospora crassa Ingold, Anguillospora filiformis Greathead, Anguillospora longissima (Sacc. \& P. Syd) Ingold, Campylospora chaetocladia Ranzoni, Colispora curvata Nawawi \& Kuthub, Heliscina campanulata Marvanova, Heliscus submerses H. I. Huds., Lunulospora curvula Ingold, Mycocentrospora acerina (R. Hartig) Deighton, Triscelophorus acuminatus Nawawi,
Table 3. One-way RM-ANOVA of abundance values of shredders (A and B), scrapers (C and D) at family level (A and C) and Chironomidae family (B and $\mathrm{D}$ ) among sampling times in a subtropical stream and the contrast analysis $(p<0.05)$. Error by sites in repeated measurements (E:S), error residuals (E:R), temporal sampling (TS) and residuals are represented.

\begin{tabular}{cccccl}
\hline ANOVA & DF & Sum Sq & F value & $\operatorname{Pr}(>\mathrm{F})$ & $\begin{array}{l}\text { Contrast } \\
\text { Analysis }\end{array}$ \\
\hline A. Invertebrate Shredders \% in family level & \\
E:S & 1 & 0.02 & 0.03 & & \\
E:R & 3 & 2.45 & & & \\
& & & & January $=$ \\
TS & 3 & 17.13 & 3.33 & 0.027 & $\begin{array}{l}\text { August }= \\
\text { April }<\end{array}$ \\
& & & & & November \\
Residuals & 51 & 80.40 & & & \\
\hline B. Invertebrate Scrapers \% in family level & \\
E:S & 1 & 115.25 & 0.55 & & \\
E:R & 3 & 624.92 & & & \\
TS & 3 & 799.02 & 1.82 & 0.155 & \\
Residuals & 51 & 6849.01 & & & \\
\hline
\end{tabular}

C. Chironomidae Shredders \% in genus level

\begin{tabular}{ccccc} 
E:S & 1 & 2.21 & 2.66 & \\
E:R & 3 & 0.27 & & \\
TS & 3 & 5.98 & 0.82 & 0.486 \\
Residuals & 51 & 91.52 & & \\
\hline
\end{tabular}

D. Chironomidae Scrapers \% in genus level

\begin{tabular}{|c|c|c|c|c|c|}
\hline E:S & 1 & 2.27 & 2.29 & & \\
\hline $\mathrm{E}: \mathrm{R}$ & 3 & 0.33 & & & \\
\hline TS & 3 & 9.32 & 3.73 & 0.019 & $\begin{array}{l}\text { January }= \\
\text { November }= \\
\text { April }< \\
\text { August }\end{array}$ \\
\hline Residuals & 51 & 31.61 & & & \\
\hline
\end{tabular}

Triscelophorus sp., Triscelophorus monosphorus Ingold, Tripospermum camelopardus Ingold and Tripospermum myr$t i$ (Lind) S. Hughes), but the structure and composition of hyphomycetes community also did not present changes among sample times (PerMANOVA; $\mathrm{F}_{(3,35)}=1.05 ; \mathrm{p}=0.379$ ).

\section{Discussion}

Invertebrate community

The low influences of invertebrates for leaf breakdown process have been recorded in many tropical streams (Gonçalves et al. 2016, Rezende et al. 2016, 2017c). Our study corroborated this evidence by showing a clear community pattern" that specific taxa (by population level) could make a high effects in the leaf breakdown process. Despite, the shredders activity increases the litter mass loss (Graça $2001)$, the low abundance $(2 \%)$ in tropical streams (Leite et al. 2016) decreases its importance compared to other decomposing organisms for breakdown process (Gonçalves 
Figure 2. Values of mass loss (A), fungal biomass (by ergosterol B), invertebrate richness (C), invertebrate density (D), shredders abundance (E) and scrapers abundance (F) among sampling times in a subtropical stream. Different letters ("a" and "b") indicate significant differences. Boxes represent the quartiles, the bold line represents the median, horizontal dashed line the mean, the vertical dashed line represents the upper and lower limits and circles the outliers.

Figure 3. Abundance values of shredders (A and B), scrapers (C and D) in family level (A and C) and Chironomidae family (B and $\mathrm{D}$ ) among sampling times in a subtropical stream. Different letters ("a" and "b") indicate significant differences. Boxes represent the quartiles, the bold line represents the median, horizontal dashed line the mean, the vertical dashed line represents the upper and lower limits and circles the outliers
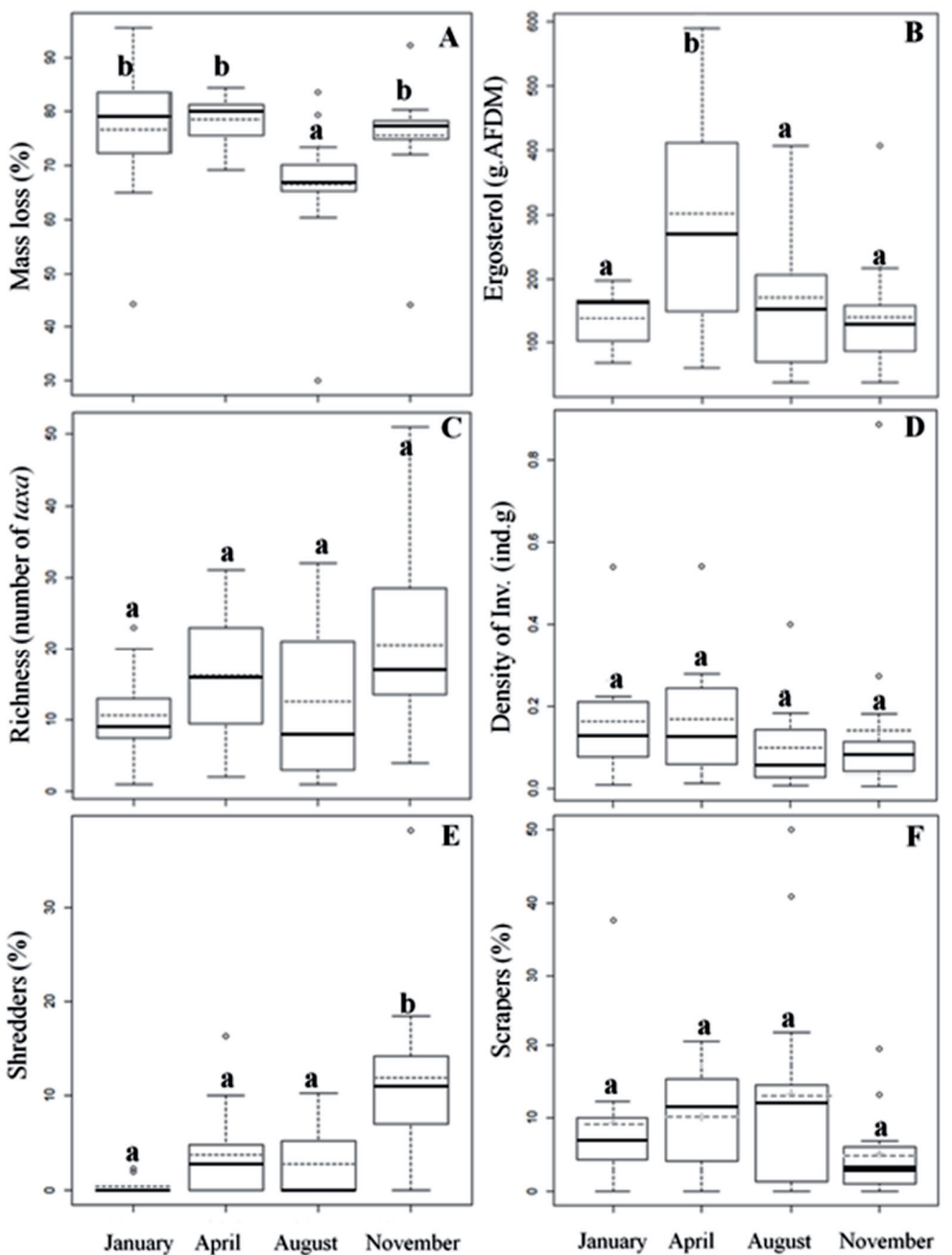

Month
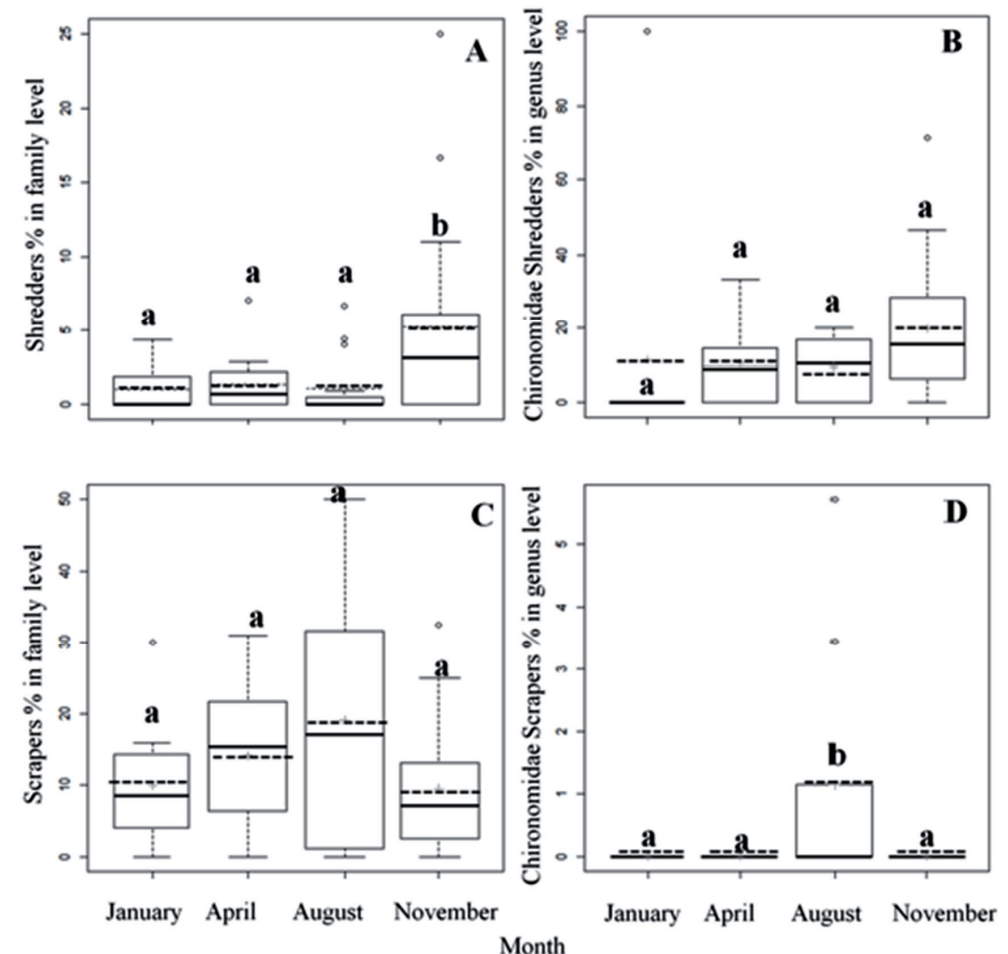
et al. 2016, Rezende et al. 2016). Also, the low shredder's abundance may open the opportunity for other group, such as scrapers, to occupy the same ecological niche (Rezende et al. 2010, 2018, Gonçalves et al. 2016).

Studies had shown that the minimum taxonomic resolution to provide a relatively accurate classification at functional feeding groups (FFG) is at least the family level (Cummins et al. 2005, Ferreira et al. 2011), while other studies pointed out the genus level (Biasi et al. 2013, Ferreira et al. 2017, Heino et al. 2018). Besides the lack of consensus, the majority of studies in tropical (Rezende et al. 2014a, 2018, Gonçalves et al. 2016) and subtropical streams (Biasi et al. 2016, Tonin et al. 2017) are at family level. This predominance in the use of the family level is probably a response to the fact that the taxonomic resolution in FFG was not extensively developed in the literature and generated some degree of confusion (Biasi et al. 2013, Ramírez and Gutiérrez-Fonseca 2014, Heino et al. 2018). In this sense, we believe that the tropical region needs a strong effort to determine the real FFG for invertebrates (studies of the stomach contents merging with isotopic signatures). We did not find variation in the abundance pattern of shredders and scrapers over time, with the exception of Chironomidae group. Considering the genus level, higher density of Chironomidae scrapers explained the low litter breakdown by the increase in microbial consumed on leaf tissue (Biasi et al. 2016, Tonin et al. 2017). These results also explained the changes in structure of invertebrate community (occurrence and frequency) among sample times. This way, our results indicated the family level as a sufficient taxonomic resolution to assess the role of shredders and scrapers in the leaf litter breakdown process. Besides, the Chironomidae family was the key to explain leaf breakdown in this study (Biasi et al. 2013, 2016).

\section{Environmental variables and ecological process}

Water temperature shows a positive relationship with leaf litter breakdown rates. Temperature was the most important factor to drive the leaf breakdown in many tropical streams (Gonçalves et al. 2016, Rezende et al. 2016). High temperature may accelerate the biological metabolism (mainly in microbial community), increasing the litter mass loss (Chauvet and Suberkropp 1998, Rezende et al. 2014a). Higher water temperature associated with limited nutrients in litter and water could also be responsible for the low shredders abundance in tropical streams (Boyero et al. 2012, Rezende et al. 2015). However, some tropical (Allan et al. 2009, Boyero et al. 2011) and subtropical (Tonin et al. 2014, 2017, Biasi et al. 2016) stream systems have high shredders abundance, and the aspects responsible for this pattern (i.e., water temperature, water nutrients and litter leaf quality) should be further studied.

The estimated decay rates (median $k=-0.046$ day $^{-1}$ ) can be described as fast, according to Gonçalves et al. (2014) categorization for tropical systems. The $k$ was intermediary compared to other subtropical (range -0.0021 to -0.238 , Biasi et al. 2013, 2016, Tonin et al. 2014, 2017), and tropical streams (-0.0001 to -0.077 ; Abelho, 2001, Moretti et al. 2007,
Gonçalves et al. 2012b, Rezende et al. 2014a, 2017a, c). The largest $k$ was observed in the warm period, which indicates a seasonal dynamics, and also explains the positive correlation with water temperature.

Fungal biomass was in the lower range compared to other subtropical streams (range 30 to $655 \mu$ g.AFDM-1; Lemes da Silva et al. 2017, Tonin et al. 2017), and tropical streams (range 50 to $1058 \mu$ g.AFDM ${ }^{-1}$, Gonçalves et al. 2006, Moretti et al. 2007, Rezende et al. 2014a, 2017c). The ergosterol amount was the highest in April compared to other months, and is probably explained by the low water wash force. The low water wash force may decrease the physical abrasion and biofilm loss on the leaf (Santos Fonseca et al. 2012) as observed by other work on tropical streams (Rezende et al. 2017c). A higher number of fungi species (14 species with sporulation) was observed in our study than in other tropical streams (3 to 6 species; Sales et al. 2015, Martins et al. 2016, Rezende et al. 2016, 2017c), probably due to the lower temperature compared to tropical streams (Graça et al. 2016). However, the structure and composition of hyphomycetes community did not present changes among sample times either, probably thanks to the lower temperature range for this community (Graça et al. 2016).

The invertebrate density and richness did not differ among sampling times. However, richness shows a positive correlation with coarse and very coarse sand. The occurrence of coarse granulometric fractions creates high habitat diversity in the sediment, increasing the availability of shelter for aquatic organisms (Bücker et al. 2010, Dominguez-Granda et al. 2011, Rezende et al. 2014b). This corroborates the theory of natural fluvial processes (Vannote et al. 1980, Vinson and Hawkins 2003) cause the local habitat characteristics (e.g., water velocity, water depth, river width and substrate) to vary spatially along the stream and structure the invertebrate communities (Rezende et al. 2014b).

\section{Conclusion}

We found a low importance of changes in taxonomic resolution for determining trophic groups to assess the influence of invertebrate community in leaf litter breakdown process in this subtropical stream. The most sensitive taxon was Chironomidae that shows difference on taxonomic resolution pattern. High density of Chironomidae scrapers at genus level help to explain low litter breakdown by increase in the consumption of microbial present on leaf tissue. This may indicate that in subtropical streams the Chironomidae family is dominant and these organisms constitute a key taxon to explain ecological processes when compared to the other families. Besides the importance of Chironomidae, we found a low importance of invertebrate community (shredders and scrapers) in leaf breakdown process, not corroborating our first hypothesis.

On the other hand, abiotic factors (mainly temperature) are the main factors responsible for the leaf litter breakdown in this subtropical system over the year. Also, the taxonomic resolution (family to genus level) did not change the results of 
the most important trophic groups (shredders and scrapers), not corroborating also our second hypothesis, probably due to the low importance of invertebrates in the stream system. Therefore, future studies should be done to investigate the real importance of invertebrates in leaf breakdown of streams.

Acknowledgements: We are grateful to CNPq (Process: 421288/2017-5 and 405290/2018-7) for financial support. RSR thanks the Post-graduate Program of Environmental Science at the Communitarian University of Chapecó Region.

\section{References}

Abelho, M. 2001. From litterfall to breakdown in streams: a review. Sci. World J. 1:656-680.

Allan, K., L. Boyero and R.G. Pearson. 2009. Chemical communication in competitive interactions among tropical stream detritivores. Trop. Zool. 22:195-204.

Bärlocher, F. 2005. Sporulation by aquatic hyphomycetes. In: M.A.S. Graça, F. Bärlocher and M.O. Gessner (eds.), Methods to Study Litter Decomposition: A Practical Guide. Springer, Dordrecht. pp. 185-187.

Bambi, P., R.S. Rezende, M.J. Feio, G.F.M. Leite, E. Alvin, J.M.B. Quintão, F. Araújo and J.F.-Jr Gonçalves. 2017. Temporal and spatial patterns in inputs and stock of organic matter in savannah streams of central Brazil. Ecosystems 20:757-768

Biasi, C., C. Cerezer and S. Santos. 2016. Biological colonization and leaf decomposition in a subtropical stream. Ecol. Austral. 26:189-199.

Biasi, C., A.M. Tonin, R.M. Restello and L.U. Hepp. 2013. The colonisation of leaf litter by Chironomidae (Diptera): The influence of chemical quality and exposure duration in a subtropical stream. Limnologica 43:427-433.

Boyero, L., R.G. Pearson, D. Dudgeon, V. Ferreira, M.A.S. Graça, M. O. Gessner, A.J. Boulton, E. Chauvet, C.M. Yule, R.J. Albariño, A. Ramírez, J.E. Helson, M. Callisto, M. Arunachalam, J. Chará, R. Figueroa, J.M. Mathooko, J.F. Gonçalves Jr, M.S. Moretti, A.M. Chará-Serna, J.N. Davies, A. Encalada, S. Lamothe, L. M. Buria, J. Castela, A. Cornejo, A.O.Y. Li, C.M'Erimba, V. D. Villanueva, M. del Carmen Zúñiga, C.M. Swan and L.A. Barmuta. 2012. Global patterns of stream detritivore distribution: implications for biodiversity loss in changing climates. Global. Ecol. Biogeogr. 21:134-141.

Boyero, L., R.G. Pearson, D. Dudgeon, M.A.S. Graça, M.O. Gessner, R.J. Albarino, V. Ferreira, C.M. Yule, A.J. Boulton, M. Arunachalam, M. Callisto, E. Chauvet, A. Ramirez, J. Chara, M.S. Moretti, J.F.-Jr Goncalves , J.E. Helson, A.M. Chara-Serna, A.C. Encalada, J.N. Davies, S. Lamothe, A. Cornejo, A.O.Y. Li, L.M. Buria, V.D. Villanueva, M.C. Zuniga and C.M. Pringle. 2011. Global distribution of a key trophic guild contrasts with common latitudinal diversity patterns. Ecology 92:1839-1848.

Bücker, A., M. Sondermann, H.-G. Frede and L. Breuer. 2010. The influence of land-use on macroinvertebrate communities in montane tropical streams - a case study from Ecuador. Fund. Appl. Limnol. 177:267-282.

Chauvet, E. and K. Suberkropp. 1998. Temperature and sporulation of aquatic hyphomycetes. Appl. Environ. Microb. 64:1522-1525.

Compin, A. and R. Céréghino. 2003. Sensitivity of aquatic insect species richness to disturbance in the Adour-Garonne stream system (France). Ecol. Indic. 3:135-142.
Crawley, M.J. 2007. The R Book. John Wiley \& Sons Ltd, England. pp. $449-488$.

Cummins, K., R. Merritt and P. Andrade. 2005. The use of invertebrate functional groups to characterize ecosystem attributes in selected streams and rivers in south Brazil. Stud. Neotrop. Fauna Environ. 40:69-89.

Cummins, K. W. 1996. An Introduction to the Aquatic Insects of North America. Kendall/Hunt Publishing Company, Dubuque.

Dolédec, S., N. Phillips and C. Townsend. 2011. Invertebrate community responses to land use at a broad spatial scale: trait and taxonomic measures compared in New Zealand rivers. Freshwater Biol. 56:1670-1688.

Dominguez-Granda, L., K. Lock and P.L.M. Goethals. 2011. Using multi-target clustering trees as a tool to predict biological water quality indices based on benthic macroinvertebrates and environmental parameters in the Chaguana watershed (Ecuador). Ecol. Inform. 6:303-308.

Ferreira, V., M.A.S. Graça, J.L.M.P. de Lima and R. Gomes. 2006. Role of physical fragmentation and invertebrate activity in the breakdown rate of leaves. Arch. Hydrobiol. 165:493-513.

Ferreira, W.R., L.U. Hepp, R. Ligeiro, D.R.R. Macedo, R.M.M. Hughes, P.R.R. Kaufmann and M. Callisto. 2017. Partitioning taxonomic diversity of aquatic insect assemblages and functional feeding groups in neotropical savanna headwater streams. Ecol. Indic. 72:365-373.

Ferreira, W.R., L.T. Paiva and M. Callisto. 2011. Development of a benthic multimetric index for biomonitoring of a neotropical watershed. Braz J. Biol. 71:15-25.

Fiuza, P.O., B.P. Ottoni-Boldrini, J.S. Monteiro, N.R. Catena, N. Hamada and L.F.P. Gusmão. 2015. First records of Ingoldian fungi from the Brazilian Amazon. Braz J. Bot. 38:615-621.

Fiuza, P.O., T. Cantillo-Perez, J.S. Monteiro, V. Gulis and L.F.P. Gusmão. 2016. Rare hyphomycetes from freshwater environments from Chapada Diamantina, Bahia, Brazil. Nova Hedwigia 104:451-466.

Gessner, M.O. 1999. A perspective on leaf litter breakdown in streams. Oikos 85:377-384

Gessner, M.O. 2005. Ergosterol as a measure of fungal biomass. In: M.A.S. Graça, F. Bärlocher and M.O. Gessner (eds.), Methods to Study Litter Decomposition: A Practical Guide. Springer, Dordrecht. pp. 189-195.

Gonçalves, J.F.-Jr., F.A. Esteves and M. Castillo. 2003. Chironomids colonization on Nymphaea ampla L. detritus during a degradative ecological succession experiment in a Brazilian coastal lagoon. Acta Limnol. Bras. 15:21-27.

Gonçalves, J.F.-Jr, S.R.M. Couceiro, R.S. Rezende, R.T. Martins, B. M.P. Ottoni-Boldrini, C.M. Campos, J.O. Silva and N. Hamada. 2016. Factors controlling leaf litter breakdown in Amazonian streams. Hydrobiologia 792:195-207.

Gonçalves, J.F.-Jr, R.T. Martins, B.M.P. Ottoni and S.R.M. Couceiro. 2014. Uma visão sobre a decomposição foliar em sistemas aquáticos brasileiros. In: N. Hamada, J.L. Nessimian, and R.B. Querino (eds.), Insetos aquáticos: biologia, ecologia e taxonomia. Editora INPA, Manaus. pp. 89-116.

Gonçalves, J.F.-Jr, R.S. Rezende, J. França and M. Callisto. 2012a. Invertebrate colonisation during leaf processing of native, exotic and artificial detritus in a tropical stream. Mar. Freshwater. Res. $63: 428-439$.

Gonçalves, J.F.-Jr, R.S. Rezende, N.M. Martins and R.S. Gregorio. 2012b. Leaf breakdown in an Atlantic Rain Forest stream. Austral Ecol. 37:807-815. 
Gonçalves, J.F., A.M. Santos and F.A. Esteves. 2004. The influence of the chemical composition of Typha domingensis and Nymphaea ampla detritus on invertebrate colonization during decomposition in a Brazilian coastal lagoon. Hydrobiologia 527:125-137.

Gonçalves, J.F.-Jr, J.S. França, A.O. Medeiros, C.A. Rosa and M Callisto. 2006. Leaf breakdown in a tropical stream. Int. Rev. Hydrobiol. 91:164-177.

González, M. and M.A.S. Graça. 2005. Influence of detritus on the structure of the invertebrate community in a small Portuguese stream. Int. Rev. Hydrobiol. 90:534-545.

Graça, M.A.S. 2001. The role of invertebrates on leaf litter decomposition in streams - a review. Int. Rev. Hydrobiol. 86:383-393.

Graça, M.A.S., V. Ferreira, C. Canhoto, A.C. Encalada, F. GuerreroBolaño, K.M. Wantzen and L. Boyero. 2015. A conceptual model of litter breakdown in low order streams. Int. Rev. Hydrobiol. 100:1-12.

Graça, M.A.S., K. Hyde and E. Chauvet. 2016. Aquatic hyphomycetes and litter decomposition in tropical - subtropical low order streams. Fungal Ecol. 19:182-189.

Gulis, V. 2005. An Illustrated key to the common temperate species of aquatic hyphomycetes. In: M.A.S. Graça, F. Bärlocher and M.O. Gessner (eds.), Methods to Study Litter Decomposition: A Practical Guide. Springer, Dordrecht. pp. 153-167.

Hamada, N., J.L. Nessimian and R.B. Querino. 2014. Insetos aquáticos na Amazônia brasileira: taxonomia, biologia e ecologia. Editora INPA, Manaus. pp. 724.

Harper, D., J. Mekotova, S. Hulme, J. White and J. Hall. 1997. Habitat heterogeneity and aquatic invertebrate diversity in floodplain forests. Global Ecol. Biogeogr. Lett. 6:275-285.

Heino, J., A.S. Melo, J. Jyrkänkallio-Mikkola, D.K. Petsch, V.S Saito, K.T. Tolonen, L.M. Bini, V.L. Landeiro, T.S.F. Silva, V. Pajunen, J. Soininen and T. Siqueira. 2018. Subtropical streams harbour higher genus richness and lower abundance of insects compared to boreal streams, but scale matters. J. Biogeogr. 45:1983-1993.

Leite, G.F.M., F.T.C. Silva, F.K.S.P. Navarro, R.D.S. Rezende and J.F.-Jr Gonçalves. 2016. Leaf litter input and electrical conductivity may change density of Phylloicus sp. (Trichoptera: Calamoceratidae) in a Brazilian savannah stream. Acta Limnol. Bras. 28:e12

Lemes, A.S., L. Kleba Lisboa, A.E. Siegloch, M.M. Petrucio and J. F.-Jr Gonçalves. 2017. Connecting the litterfall temporal dynamics and processing of coarse particulate organic matter in a tropical stream. Mar. Freshwater. Res. 68:1260-1271.

Ligeiro, R., M.S. Moretti, J.F.-Jr Goncalves and M. Callisto. 2010 What is more important for invertebrate colonization in a stream with low-quality litter inputs: exposure time or leaf species? Hydrobiologia 654:125-136.

Martins, R.T., A.S. Melo, J.F. Gonçalves, C.M. Campos and N. Hamada. 2016. Effects of climate change on leaf breakdown by microorganisms and the shredder Phylloicus elektoros (Trichoptera: Calamoceratidae). Hydrobiologia 789:31-44.

Moretti, M., J.F.-Jr Gonçalves and M. Callisto. 2007. Leaf breakdown in two tropical streams: Differences between single and mixed species packs. Limnologica 37:250-258.

Moulton, T.P., S.A.P. Magalhaes-Fraga, E.F. Brito and F.A. Barbosa. 2010. Macroconsumers are more important than specialist macroinvertebrate shredders in leaf processing in urban forest streams of Rio de Janeiro, Brazil. Hydrobiologia 638: 55-66.

Oksanen, J., R. Kindt, P. Legendre, B. O'Hara, G.L. Simpson, P. Solymos, M.H.H. Stevens and H. Wagner. 2008. Adonis function. In Vegan: Community Ecology Package. R package version 1.13-1. pp. $15-20$
Oliveira-Filho, A.T., J.A. Jarenkow and M.J.N. Rodal. 2006. Floristic relationships of seasonally dry forests of eastern south america based on tree species distribution patterns. In: R.T. Pennington, G.P. Lewis and J.A. Ratter (eds.), Neotropical Savannas and Seasonally Dry Forests: Plant Diversity, Biogeography, and Conservation. CRC Press - Taylor \& Francis. pp. 159-192.

Pérez, G.P. 1988. Guía para el estudio de los macroinvertebrados acuáticos del departamento de Antioquia. Editorial Presencia, Bogotá. pp. 1-228.

Ramírez, A. and P.E. Gutiérrez-Fonseca. 2014. Functional feeding groups of aquatic insect families in Latin America: a critical analysis and review of existing literature. Rev. Biol. Trop. 64: $155-167$.

R Core Team (2019). R: A language and environment for statistical computing. R Foundation for Statistical Computing, Vienna, Austria. URL https://www.R-project.org/.

Rezende, R. de S., G.F.M. Leite, A.K.S. De-Lima, L.A.B. Da Silva Filho, C.V.C. Chaves, A.C.H. Prette, J.S. Freitas and J.F.-Jr Gonçalves. 2015. Effects of density and predation risk on leaf litter processing by Phylloicus sp. Austral Ecol. 40:693-700.

Rezende, R.S., P.R.S. Correia, J.F.-Jr Gonçalves and A.M. Santos. 2017a. Organic matter dynamics in a savanna transition riparian zone: input of plant reproductive parts increases leaf breakdown process. J. Limnol. 76:502-511.

Rezende, R.S., M.A.S. Graça, A.M. dos Santos, A.O. Medeiros, P. F. Santos, Y.R. Nunes, J.F.-Jr Gonçalves. 2016. Organic matter dynamics in a tropical gallery forest in a grassland landscape. Biotropica 48:301-310.

Rezende, R.S., J.F.-Jr Gonçalves and M.M. Petrucio. 2010. Leaf breakdown and invertebrate colonization of Eucalyptus grandis (Myrtaceae) and Hirtella glandulosa (Chrysobalanaceae) in two Neotropical lakes. Acta Limnol. Bras. 22:23-34.

Rezende, R.S., J.L.C. Novaes, C.Q. Albuquerque, R.S. Costa and J. F. Gonçalves. 2018. Aquatic invertebrates increase litter breakdown in Neotropical shallow semi-arid lakes. J. Arid Environ. 154:8-14.

Rezende, R.S., M.M. Petrucio and J.F.-Jr Gonçalves. 2014a. The effects of spatial scale on breakdown of leaves in a tropical watershed. PLoS One 9:e97072.

Rezende, R.S., M.A. Sales, F. Hurbath, N. Roque, J.F.-Jr Gonçalves and A.O. Medeiros. 2017b. Effect of plant richness on the dynamics of coarse particulate organic matter in a Brazilian Savannah stream. Limnologica 63:57-64.

Rezende, R.S., A.M. Santos, C. Henke-Oliveira and J.F.-Jr Gonçalves. 2014b. Effects of spatial and environmental factors on benthic a macroinvertebrate community. Zool. 31:426-434.

Rezende, R.S., A.M. Santos, A.O. Medeiros and J.F. Gonçalves-Jr. 2017 c. Temporal leaf litter breakdown in a tropical riparian forest with an open canopy. Limnetica 36:445-459.

Rueda-Delgado, G., K.M. Wantzen and M.B. Tolosa. 2006. Leaflitter decomposition in an amazonian floodplain stream: effects of seasonal hydrological changes. J. N. Am. Benthol. Soc. 25: $233-249$

Sales, M.A., J.F. Goncalves Jr., J.S. Dahora, A.O. Medeiros, J.F.-Jr Gonçalves, J.S. Dahora and A.O. Medeiros. 2015. Influence of leaf quality in microbial decomposition in a headwater stream in the brazilian cerrado: a 1-year study. Microb. Ecol. 69:84-94.

Santos Fonseca, A.L., I. Bianchini, C.M.M. Pimenta, C.B.P. Soares and N. Mangiavacchi. 2012. The flow velocity as driving force for decomposition of leaves and twigs. Hydrobiologia 703:5967.

Suguio, K. 1973. Introdução à sedimentologia. Edgard Blucher, São Paulo. pp. 317. 
Tonin, A.M., L.U. Hepp and J.F.-Jr Gonçalves. 2017. Spatial variability of plant litter decomposition in stream networks: from litter bags to watersheds. Ecosystems 21:567-58.

Tonin, A.M., L.U. Hepp, R.M. Restello and J.F.-Jr Gonçalves. 2014. Understanding of colonization and breakdown of leaves by invertebrates in a tropical stream is enhanced by using biomass as well as count data. Hydrobiologia 740:79-88.

Vannote, R.L., G.W. Minshall, K.W. Cummins, J.R. Sedell and C.E. Cushing. 1980. River continuuum concept. Can. J. Fish. Aquat. Sci. 37:130-137.

Vinson, M.R. and C.P. Hawkins. 2003. Broad-scale geographical patterns in local stream insect genera richness. Ecography 26: 751-767.

Wang, L., S. Deng, S. Qiu and Y. Yan. 2017. Trophic dynamics of macroinvertebrate communities of a subtropical river in China. Int. Rev. Hydrobiol. 102:59-69.

Received November 22, 2018 Revised February 18, March 14, 2019 Accepted March 17, 2019

\section{Supplementary material}

Figure SM1. Arrangement of buckets (vertical input), represented by the circles, along a stretch of 100 meters in the stream.

Table SM2. Presence of the taxa in temporal periods in a subtropical stream.

Table SM3. Classification of functional feeding groups of the taxa in a subtropical stream.

The appendix may be downloaded from www.akademiai. com. 